\title{
Heterosis for Morpho-Biochemical Traits in Brinjal (Solanum melongena L.) During Kharif Season
}

\author{
Jamini Saikia $^{1 *}$, N. S. Barua ${ }^{2}$, D. B. Phookan ${ }^{1}$ and P. Das ${ }^{3}$ \\ ${ }^{1}$ Department of Horticulture, Assam Agricultural University, Jorhat, 785013, India \\ ${ }^{2}$ Department of Plant Breeding and Genetics, Assam Agricultural University, \\ Jorhat, 785013, India \\ ${ }^{3}$ Department of Biochemistry and Agricultural Chemistry, Assam Agricultural University, \\ Jorhat, 785013, India \\ *Corresponding author
}

\section{A B S T R A C T}

\section{Keywords}

Brinjal,

Biochemical, Morphological, Heterosis, Kharif

Article Info

Accepted:

24 August 2019

Available Online:

10 September 2019
A field investigation was undertaken in brinjal (Solanum melongena L.) during kharif, 2017 to identify potential parental combinations in order to have superior hybrids and extent of heterosis in $\mathrm{F}_{1}$ hybrid over mid parent and better parent during kharif. All the four $\mathrm{F}_{1}$ progeny, JC-1 x Khoruah-1, Brinjal-3 x JC-1, Brinjal-1 x PPL and Kuchia x JC-1 exhibited high mid parent and better parent heterosis for yield and yield attributing traits. Three hybrids namely, JC-1 x Khoruah-1, Brinjal-3 x JC-1 and Kuchia x JC-1 showed high negative better parent heterosis for days to first and $50 \%$ flowering except Brinjal- $1 \mathrm{x}$ PPL. All the four $\mathrm{F}_{1}$ progeny viz., JC-1 x Khoruah-1, Brinjal-3 x JC-1, Brinjal-1 x PPL and Kuchia $\mathrm{x}$ JC-1 were found to be promising for kharif season. Promising $\mathrm{F}_{1}$ hybrids could be utilized as high yielding varieties after systematic multi- location trials in different agroclimatic zones of Assam along with disease- and pest-resistance tests as well as quality tests.

\section{Introduction}

Brinjal (Solanum melongena L.) is grown throughout the year. Brinjal is a common and popular vegetable crop in the subtropics and tropics. Brinjal is grown in an area of 733 ('000 hectare) with a total production of 12510 ('000 MT) and the productivity of 17.07 (MT/ha). In Assam, it is cultivated both in rabi and kharif seasons with an area of 17.67 ('000 hectare), production 286.43 ('000 MT) and the productivity of 16.21 (MT/ha)
(National Horticulture Board, 2016-17). India has wide range of variability in brinjal crop. In spite of a large number of varieties, only a few have yield potentiality during kharif season. Although, India has developed many hybrids of brinjal cultivar which gives better quality and yield during rabi season, but these characters were not found in kharif season. However, in the face of increasing population, there is a need for increased production and productivity of brinjal for both the seasons. This fact draws the attention of plant breeders 
to identify and/or superior varieties and hybrids with higher yield and better quality during kharif season to mitigate the needs of the people and also to maximise the yield of the brinjal crop. To overcome the problem of low performance during kharif, there remains a need to explore or collect different brinjal genotypes from various places and to evaluate brinjal genotypes for superiority over existing cultivars and for their direct use as varieties or as parents in development of superior hybrids for the kharif season. Therefore, the present investigation was carried out to identify potential parental combinations in order to have superior hybrids and extent of heterosis in $F_{1}$ hybrid over mid parent and better parent of six parents.

\section{Materials and Methods}

The present experiment was carried out in the Department of Horticulture, Assam Agricultural University, Jorhat during kharif, 2017. Six parental lines were selected for crossing in respect of high yield, more number of fruits per plant and more number of primary branches per plant during kharif season and the crosses were made within these six parental genotypes in a crossing nursery block during rabi, 2015-2016 and four $F_{1}(s)$ were generated. The parental lines and $\mathrm{F}_{1}(\mathrm{~s})$ were grown in a Randomized Block Design with three replications during kharif, 2017. The row to row and plant to plant spacing were maintained at $75 \mathrm{~cm} \times 60 \mathrm{~cm}$, respectively. All the package of practices was followed to raise a healthy crop. The cross combinations are presented in Table1.

The mean of all the replications for each parent and hybrids for each of the characters was computed and used in estimation of heterosis. Heterosis was calculated as the percentage increase or decrease of mean of $\overline{\mathrm{F}}_{1}$ performance over the means of average parent $\overline{(\mathrm{MP})}$ and the better parent $\overline{(\mathrm{BP})}$

Heterosis over the mid parent $(\%)$

$$
=\frac{\overline{\mathrm{F}_{1}}-\overline{\mathrm{MP}}}{\overline{\mathrm{MP}}} \times 100 \quad \overline{\mathrm{MP}} \text { value }=\frac{\mathrm{P}_{1}+\mathrm{P}_{2}}{2}
$$

(Average or mid parent heterosis)

Where, ${ }^{\overline{\mathrm{MP}}}$ is the mean of parent involved in development of respective $F_{1}$ and $\bar{F}_{1}$ is mean of $\mathrm{F}_{1}$ hybrids

Heterosis over the better parent (\%) $=\frac{\overline{\mathrm{F}}_{1}-\overline{\mathrm{BP}}}{\overline{\mathrm{BP}}} \times 100$

\section{(Heterobeltiosis)}

Where, $\overline{\mathrm{BP}}$ is the mean of the better parent among parents involved in development of $F_{1}$ hybrid for each character.

\section{Testing of significance of amount of} heterosis

The test used for testing magnitude of heterosis is the t-test. The value of $t$ is calculated as,

$\mathrm{t}=\frac{\mathrm{H}}{\mathrm{SE}_{\mathrm{H}}}$

Where,

$\mathrm{H}=$ Amount of heterosis

$\mathrm{SE}_{\mathrm{H}}=$ Standard error for heterosis $(\mathrm{H})$

The $\mathrm{SE}_{\mathrm{H}}$ for two different types of heterosis were obtained as follows:

$\mathrm{SE}$ for $(\mathrm{MP})=\frac{\sqrt{3 \times \mathrm{Me}}}{2 \mathrm{r}} \mathrm{SE}$ for $(\mathrm{BP})=\frac{\sqrt{2 \times \mathrm{Me}}}{\mathrm{r}}$ 
Where, $\mathrm{M}_{\mathrm{e}}=$ Error mean square

\section{Results and Discussion}

\section{Morphological traits}

\section{Plant height (cm)}

Per cent $F_{1}$ heterosis over mid parent and better parent for plant height was presented in Table2. The plant height is one of the important character that support yield and its component traits. The data on heterosis support that some of the crosses were found taller whereas some are found shorter than their parents.

Among all the hybrids, Brinjal-1 $x$ PPL recorded the highest mid parent and better parent heterosis (16.93\% and $13.35 \%)$. Similar findings with positive heterosis over MP have also been reported by earlier workers like Dubey et al., (2014), Reddy and Patel (2014), Makani et al., (2013) and Pachiyappan et al., (2012).

\section{Plant spread (cm)}

All the hybrids showed highly significant positive heterosis over MP and BP for plant spread. The highest significant positive heterosis for MP was exhibited by Kuchia $\mathrm{x}$ JC-1 (18.18\%) which was followed by JC-1 x Khoruah-1(15.26\%), Brinjal-1 X PPL (13.88\%) and Brinjal-3 x JC-1 (13.20\%), respectively. The hybrids JC-1 x Khoruah-1 $(13.60 \%)$ recorded the highest positive heterosis over BP which was at par with Kuchia x JC-1 (13.21\%).

\section{Number of primary branches per plant}

More number of primary branches per plant was the major parameter which supports yield and its component traits. In the present investigation for number of primary branches per plant presented in Table 2 revealed that all the hybrids exhibited highly significant positive heterosis over MP and BP. The hybrid Kuchia x JC-1 (28.38\% and 2.50\%) exhibited the highest significant positive heterosis over MP and BP. The F1 Brinjal-1 x PPL $(2.83 \%)$ and Kuchia x JC-1 (2.50\%) showed significant positive heterosis over BP and JC-1 x Khoruah-1 (-16.95\%) and Brinjal$3 \mathrm{x}$ JC-1 (-17.17\%) exhibited negative heterosis over BP.

These results are in conformity with the earlier finding of Reddy and Patel (2014) and Joshi et al., (2008).

\section{Leaf blade length $(\mathrm{cm})$}

Per cent $\mathrm{F}_{1}$ heterosis over MP and $\mathrm{BP}$ for leaf blade length was presented in Table2. Among the hybrids none of the hybrids showed significant negative MP heterosis. The highest positive MP heterosis was recorded for JC-1 x Khoruah-1 (8.80\%) and lowest was observed for Brinjal-3 x JC-1 (3.90\%). However, two hybrids Kuchia x JC-1 (17.99\%) and Brinjal-1 $x$ PPL (13.41\%) showed highly significant positive heterosis and Brinjal-3 x JC-1 ($11.33 \%)$ and JC-1 x Khoruah-1 (-6.95\%) exhibited negative BP heterosis.

\section{Leaf blade width $(\mathrm{cm})$}

All the hybrids showed highly significant positive heterosis over MP heterosis. The $F_{1}$, Brinjal-1 $\mathrm{x}$ PPL exhibited the highest significant positive heterotic effect over MP (21.39\%) followed by JC-1 x Khoruah-1 (5.20\%), Brinjal-3 x JC-1 (1.81\%) and Kuchia x JC-1 (1.13\%), respectively. Brinjal-1 x PPL $(12.20 \%)$ recorded highest positive heterosis over BP which was followed by JC-1 x Khoruah-1 (0.45\%). The hybrid, Kuchia x JC$1(-8.14 \%)$ and Brinjal-3 x JC-1 (-4.38\%) showed significant negative heterosis over BP. 


\section{Number of leaf prickles}

A highly significant positive heterosis was observed for MP and BP heterosis for number of leaf prickles. Brinjal-1 x PPL (63.96\%) recorded the highest significant MP which was followed by Brinjal-3 x JC-1 (42.00\%) and JC-1 x Khoruah-1 (34.66\%), respectively. Kuchia x JC-1 (18.42\%) recorded the lowest positive heterosis over MP but same hybrid also recorded highest significant positive $\mathrm{BP}$ (27.08\%) which was followed by JC-1 x Khoruah-1 (25.67\%). The lowest positive BP heterosis was observed for Brinjal-3 x JC-1 $(1.10 \%)$.

\section{Days to first flowering}

Among the hybrids, Brinjal-1 x PPL (5.24\%) and Brinjal-3 x JC-1 (3.58\%) exhibited the significant positive heterosis over MP. JC-1 $\mathrm{x}$ Khoruah-1 and Kuchia $\mathrm{x}$ JC-1 showed significant negative heterosis over MP ($4.50 \%)$ and $(-6.95 \%)$. JC-1 x Khoruah-1 ($11.22 \%)$, Brinjal-3 x JC-1 (-3.97\%) and Kuchia x JC-1 (-14.18\%) exhibited highly significant positive heterosis over BP. Only Brinjal-1 x PPL (4.96\%) showed positive heterosis over BP. This finding was supported by Desai et al., (2016), Dubey et al., (2014), Biswas et al., (2013), Dudhat et al., (2013), Singh et al., (2012), Chowdhury et al., (2010) and Joshi et al., (2008).

\section{Days to 50\% flowering}

The mid parent/average heterosis for days to $50 \%$ flowering was presented in Table3. Among the hybrids, Kuchia x JC-1 (-6.88\%) and JC-1 x Khoruah-1 (-3.70\%) showed significant negative heterosis over MP. Brinjal-3 x JC-1 (3.65\%) and Brinjal-1 x PPL (1.44\%) showed significant positive heterosis over MP. A significant negative heterosis over BP was observed for days to $50 \%$ flowering. The hybrid Kuchia x JC-1 (-
$10.24 \%)$ exhibited the highest negative BP. Only the hybrid Brinjal-1 x PPL (0.78\%) recorded positive heterosis over better parent. Positive and negative heterosis for better parent was also observed by earlier workers Ansari et al., (2009) and Chadha et al., (2001).

\section{Fruit pedicel length $(\mathrm{cm})$}

All the hybrids showed highly significant positive heterosis over MP. The highest positive and highly significant MP heterosis was estimated for the hybrid JC-1 x Khoruah$1(7.04 \%)$ followed by Brinjal-3 x JC-1 $(6.13 \%)$ and Kuchia x JC-1 (4.03\%). The lowest estimate of positive heterosis for fruit pedicel length was exhibited by Brinjal-1 $\mathrm{x}$ PPL $(2.57 \%)$.

However, Kuchia x JC-1 (0.92\%) showed significant positive heterosis over BP. Three hybrids Brinjal-3 x JC-1 (-13.16\%), JC-1 x Khoruah-1 (-3.91\%) and Brinjal-1 x PPL ($3.62 \%)$ exhibited the negative heterosis over BP.

\section{Fruit length (cm)}

Table3 represents the per cent $F_{1}$ heterosis over MP and BP for fruit length. Among the hybrids, Brinjal-3 x JC-1 (32.00\%) showed highest significant positive heterosis over MP which was followed by JC-1 x Khoruah-1 (28.97\%). Brinjal-1 x PPL (-6.43\%) recorded the negative heterosis over MP. However, none of the hybrids showed positive BP heterosis for fruit length. The hybrid Brinjal-1 $x$ PPL $(-22.22 \%)$ exhibited highly significant negative $\mathrm{BP}$ heterosis which was followed by Brinjal-3 x JC-1 (-15.37\%), JC-1 x Khoruah-1 $(-13.08 \%)$. The lowest negative BP heterosis was recorded for Kuchia x JC-1 (-0.14\%). These results are in conformity with the findings of Chowdhury et al., (2010) and Timmapur et al., (2008). 
Table.2 Per cent $\mathrm{F}_{1}$ heterosis over mid parent (MP) and better parent (BP) for growth related traits (kharif, 2017)

\begin{tabular}{|c|c|c|c|c|c|c|c|c|c|c|c|c|}
\hline \multirow[t]{2}{*}{ Genotypes } & \multicolumn{2}{|c|}{$\begin{array}{c}\text { Plant height } \\
\text { (cm) }\end{array}$} & \multicolumn{2}{|c|}{$\begin{array}{l}\text { Plant spread } \\
(\mathrm{cm})\end{array}$} & \multicolumn{2}{|c|}{$\begin{array}{c}\text { Number of } \\
\text { primary branches } \\
\text { per plant }\end{array}$} & \multicolumn{2}{|c|}{$\begin{array}{l}\text { Leaf blade } \\
\text { length }(\mathrm{cm})\end{array}$} & \multicolumn{2}{|c|}{$\begin{array}{l}\text { Leaf blade width } \\
\qquad(\mathrm{cm})\end{array}$} & \multicolumn{2}{|c|}{$\begin{array}{c}\text { Number of leaf } \\
\text { prickles }\end{array}$} \\
\hline & MP & BP & MP & BP & MP & BP & MP & BP & MP & BP & MP & BP \\
\hline $\begin{array}{l}\text { JC- } \\
1 \times \text { Khoruah-1 }\end{array}$ & $11.70 *$ & $9.44 * *$ & $15.26 * *$ & $13.60 * *$ & $11.64 * *$ & $-16.95 * *$ & $8.80 * *$ & $-6.95 * *$ & $5.20 * *$ & 0.45 & $34.66 * *$ & $25.67 * *$ \\
\hline $\begin{array}{l}\text { Brinjal-3 } \times \mathrm{JC}- \\
1\end{array}$ & 8.62 & $5.93 * *$ & $13.20 *$ & $10.84 * *$ & $8.56^{* *}$ & $-17.17 * *$ & $3.90 * *$ & $-11.33 * *$ & 1.81 & $-4.38 * *$ & $42.00 * *$ & 1.10 \\
\hline $\begin{array}{l}\text { Brinjal- } \\
1 \times \text { PPL }\end{array}$ & $16.93 * *$ & $13.35 * *$ & $13.88 * *$ & $7.71 * *$ & $17.77 * *$ & $2.83 * *$ & $5.93 * *$ & $13.41 * *$ & $21.39 * *$ & $12.20 * *$ & $63.96 * *$ & $9.37 * *$ \\
\hline Kuchia $\times$ JC-1 & 8.35 & 3.46 & $18.18 * *$ & $13.21 * *$ & $28.38 * *$ & $2.50 * *$ & $5.12 * *$ & $17.99 * *$ & 1.13 & $-8.14 * *$ & $18.42 * *$ & $27.08 * *$ \\
\hline SE $( \pm)$ & 4.91 & 1.89 & 4.72 & 1.82 & 1.34 & 0.52 & 1.11 & 0.43 & 1.14 & 0.44 & 1.61 & 0.62 \\
\hline
\end{tabular}

\# Significance has been tested for estimates of $\overline{\mathrm{F} 1}-\overline{\mathrm{MP}}$ and $\overline{\mathrm{F} 1}-\overline{\mathrm{BP}}$

Table.3 Per cent $\mathrm{F}_{1}$ heterosis over mid parent (MP) and better parent (BP) for flower and fruit related traits (kharif, 2017)

\begin{tabular}{|c|c|c|c|c|c|c|c|c|c|c|}
\hline \multirow[t]{2}{*}{ Genotypes } & \multicolumn{2}{|c|}{$\begin{array}{l}\text { Days to first } \\
\text { flower }\end{array}$} & \multicolumn{2}{|c|}{$\begin{array}{c}\text { Days to } 50 \% \\
\text { flower }\end{array}$} & \multicolumn{2}{|c|}{$\begin{array}{l}\text { Fruit pedicel length } \\
\text { (cm) }\end{array}$} & \multicolumn{2}{|c|}{$\begin{array}{l}\text { Fruit length } \\
(\mathrm{cm})\end{array}$} & \multicolumn{2}{|c|}{$\begin{array}{l}\text { Fruit circumference } \\
\qquad(\mathbf{c m})\end{array}$} \\
\hline & MP & BP & MP & BP & MP & BP & MP & BP & MP & BP \\
\hline JC-1 $\times$ Khoruah-1 & -4.50 & $-11.22 * *$ & -3.70 & $-8.67 * *$ & $7.04 * *$ & $-3.91 * *$ & $28.97 * *$ & $-13.08 * *$ & $71.49 * *$ & $44.94 * *$ \\
\hline Brinjal-3 × JC-1 & 3.58 & $-3.97 * *$ & 3.65 & -1.62 & $6.13^{* *}$ & $-13.16 * *$ & $32.00 * *$ & $-15.37 * *$ & $34.68 * *$ & $45.65 * *$ \\
\hline Brinjal-1 X PPL & 5.24 & $4.96 * *$ & 1.44 & 0.78 & $2.57 * *$ & $-3.62 * *$ & $-6.43 * *$ & $-22.22 * *$ & $8.77 * *$ & $-3.44 * *$ \\
\hline
\end{tabular}

\# Significance has been tested for estimates of $\overline{\mathrm{F} 1}-\overline{\mathrm{MP}}$ and $\overline{\mathrm{F} 1}-\overline{\mathrm{BP}}$ 
Table.4 Per cent $\mathrm{F}_{1}$ heterosis over mid parent (MP) and better parent (BP) for fruit related traits (kharif, 2017)

\begin{tabular}{|c|c|c|c|c|c|c|c|c|}
\hline \multirow[t]{2}{*}{ Genotypes } & \multicolumn{2}{|c|}{ Number of fruits/plant } & \multicolumn{2}{|c|}{ Fruit weight (g) } & \multicolumn{2}{|c|}{$\begin{array}{c}\text { Fruit yield per plant } \\
(\mathrm{kg})\end{array}$} & \multicolumn{2}{|c|}{ Fruit yield (t/ha) } \\
\hline & MP & BP & MP & BP & MP & BP & MP & BP \\
\hline JC-1 $\times$ Khoruah-1 & 9.03 & $-41.47 * *$ & 98.30 & $56.06 * *$ & $160.16^{* *}$ & $48.56 * *$ & $113.81 * *$ & $21.27 *$ \\
\hline Brinjal-3 × JC-1 & -13.86 & $-54.39 * *$ & 88.62 & 24.47 & $131.20 * *$ & $31.66 * *$ & $93.96 * *$ & 10.22 \\
\hline Brinjal-1 X PPL & 59.77 & -17.03 & 41.17 & 4.20 & $162.37 * *$ & $41.24 * *$ & $173.10 * *$ & $50.19 * *$ \\
\hline Kuchia $\times$ JC-1 & 49.94 & -20.53 & -4.18 & -26.03 & $85.35 * *$ & $2.21 *$ & $76.27 * *$ & -0.34 \\
\hline SE $( \pm)$ & 31.72 & 12.21 & 49.81 & 19.17 & 2.56 & 0.98 & 24.07 & 9.26 \\
\hline
\end{tabular}

$* \mathrm{P} \leq 0.05$ $* * \mathrm{P} \leq 0.01$

\# Significance has been tested for estimates of $\overline{\mathrm{F} 1}-\overline{\mathrm{MP}}$ and $\overline{\mathrm{F} 1}-\overline{\mathrm{BP}}$

Table.5 Per cent $\mathrm{F}_{1}$ heterosis over mid parent (MP) and better parent (BP) for biochemical traits (kharif, 2017)

\begin{tabular}{|c|c|c|c|c|c|c|c|c|c|c|c|c|}
\hline \multirow[t]{2}{*}{ Genotypes } & \multicolumn{2}{|c|}{$\begin{array}{c}\text { Moisture } \\
\text { content } \\
(\%, F W)\end{array}$} & \multicolumn{2}{|c|}{$\begin{array}{c}\text { Crude fiber } \\
\text { content }(\%, D W)\end{array}$} & \multicolumn{2}{|c|}{$\begin{array}{l}\text { Crude protein } \\
(\%, D W)\end{array}$} & \multicolumn{2}{|c|}{$\begin{array}{c}\text { Ascorbic acid } \\
(\mathrm{mg} / 100 \mathrm{~g} \text { FW) }\end{array}$} & \multicolumn{2}{|c|}{$\begin{array}{c}\text { Solasodine } \\
\text { content (mg/100g } \\
\text { DW) }\end{array}$} & \multicolumn{2}{|c|}{$\begin{array}{c}\text { Total phenol } \\
\text { (mg GAE/g FW) }\end{array}$} \\
\hline & MP & BP & MP & BP & MP & BP & MP & BP & MP & BP & MP & BP \\
\hline $\begin{array}{l}\text { JC- } \\
1 \times \text { Khoruah-1 }\end{array}$ & 2.10 & 2.07 & $-5.02 * *$ & $2.04 * *$ & $\begin{array}{l}18.69 * \\
*\end{array}$ & $1.44 * *$ & $\begin{array}{l}2.98 * \\
*\end{array}$ & $\begin{array}{l}2.33 * \\
*\end{array}$ & $-\overline{15.52 * *}$ & $-9.40 * *$ & $-12.74 * *$ & $65.98 * *$ \\
\hline $\begin{array}{l}\text { Brinjal-3 } \times \mathrm{JC}- \\
1\end{array}$ & 1.97 & 0.88 & $\begin{array}{l}15.51 * \\
*\end{array}$ & $41.28 * *$ & $9.11 * *$ & $8.14 * *$ & $\begin{array}{l}5.30 * \\
*\end{array}$ & 0.93 & $-9.55^{* *}$ & $-8.39 * *$ & $-24.57 * *$ & $80.41 * *$ \\
\hline $\begin{array}{l}\text { Brinjal- } \\
1 \times \text { PPL }\end{array}$ & 0.20 & -1.53 & $1.04 *$ & $50.00 * *$ & $\begin{array}{l}13.85^{*} \\
*\end{array}$ & $-5.13 * *$ & 2.74 & $-1.30 *$ & $2.92 * *$ & $\begin{array}{l}11.94 * \\
*\end{array}$ & $2.26 * *$ & $75.19 * *$ \\
\hline Kuchia $\times$ JC-1 & 1.81 & -0.03 & $\begin{array}{l}- \\
24.70 * \\
*\end{array}$ & $-15.96 * *$ & $\begin{array}{l}13.30^{*} \\
*\end{array}$ & $\begin{array}{l}12.72 * \\
*\end{array}$ & $\begin{array}{l}4.12 * \\
*\end{array}$ & 0.22 & $1.49 *$ & $\begin{array}{l}26.46^{*} \\
*\end{array}$ & $-7.48 * *$ & $72.16 * *$ \\
\hline SE $( \pm)$ & 5.09 & 1.96 & 0.46 & 0.18 & 0.25 & 0.10 & 1.38 & 0.53 & 0.61 & 0.23 & 0.64 & 0.25 \\
\hline
\end{tabular}

\# Significance has been tested for estimates of $\overline{\mathrm{F} 1}-\overline{\mathrm{MP}}$ and $\overline{\mathrm{F} 1}-\overline{\mathrm{BP}}$ 
Table. $1 \mathrm{~F}_{1}$ cross combinations

\begin{tabular}{|c|l|}
\hline Sl. No. & Genotypes \\
\hline 1. & JC-1 x Khoruah-1 \\
\hline 2. & Brinjal-3 x JC-1 \\
\hline 3. & Brinjal-1 x Pusa Purple Long \\
\hline 4. & Kuchia x JC-1 \\
\hline
\end{tabular}

Positive heterosis over MP for fruit length was earlier reported by Dubey et al., (2014), Reddy and Patel (2014), Biswas et al., (2013), Makani et al., (2013) and Pachiyappan et al., (2012). Fruit length and Fruit girth are important traits for deciding consumer preference. In Assam, high fruit length is preferred. Therefore, the crosses showing positive heterosis for fruit length are preferable. Hence, long fruit development is prerequisite for any hybrid breeding programme.

\section{Fruit circumference (cm)}

The highest estimate of significant positive heterosis for fruit circumference was observed for JC-1 x Khoruah-1 (71.49\%) which was followed by Brinjal-3 x JC-1 (34.68 per cent), Brinjal-1 x PPL (8.77 per cent) and Kuchia $x$ JC-1 (4.59\%), respectively. Brinjal-3 x JC-1 (45.65\%) and JC-1 x Khoruah-1 (44.94\%) recorded highly significant positive BP heterosis. Other two hybrids, Kuchia x JC-1 (4.04\%) and Brinjal-1 x PPL (-3.44\%) showed significant negative BP heterosis. Balwani et al., (2017) reported similar results with significant positive standard heterosis for fruit girth and fruit weight.

\section{Number of fruits per plant}

The number of fruits per plant directly influences the yield of crop plants hence emphasis is taken to develop such a hybrids bear higher number of fruit per plant. For higher number of fruits/plant improvement can be achieved by utilizing variable parents and progenies. In the present investigation, MP heterosis for number of fruits per plant as presented in Table4 revealed that highest significant positive MP heterosis was recorded for Brinjal-1 x PPL (59.77\%). In regard to $\mathrm{BP}$, all hybrids showed highly significant nagative BP heterosis.

The highest negative $\mathrm{BP}$ heterosis was recorded for Brinjal-3 x JC-1 (-47.49\%) followed by JC-1 x Khoruah-1 (-41.47\%), Kuchia x JC-1 (-20.53\%) and Brinjal-1 x PPL $(-17.03 \%)$. Similar results were reported by earlier workers Desai et al., (2016), Biswas et al., (2013) and Chowdhury et al., (2010).

\section{Fruit weight}

Table4 represents the per cent heterosis of fruit weight and it showed that JC-1 x Khoruah-1 (98.30\%) exhibited the highly significant maximum positive MP which was followed by Brinjal-3 x JC-1 (88.62\%) and Brinjal-1 x PPL (41.17\%), respectively. Whereas, the hybrid Kuchia x JC-1 (-4.18\%) showed significant negative MP heterosis. Three hybrids namely, JC-1 x Khoruah-1 (56.06\%), Brinjal-3 x JC-1 (24.47\%) and Brinjal-1 x PPL (4.20\%) exhibited significant positive MP heterosis.

However, only one hybrid Kuchia x JC-1 ($26.03 \%$ ) recorded significant negative BP heterosis. This result was confirmed with the findings of Dubey et al., (2014), Reddy and Patel (2014), Biswas et al., (2013), Makani et al., (2013), Pachiyappan et al., (2012), Nalini et al., (2011) and Suneetha et al., (2008). 


\section{Fruit yield per plant (kg)}

Per cent $F_{1}$ heterosis for fruit yield per plant was presented in Table4 and it revealed that all the four $F_{1}$ hybrids showed highly significant positive MP and BP heterosis. The positive increase in total yield per plant over mid parent ranged from $162.37 \%$ (Brinjal-1 x PPL) to $85.35 \%$ (Kuchia $x \quad$ JC-1). Heterobeltiosis for yield per plant ranged from $48.56 \%$ (JC-1 x Khoruah-1) to $2.21 \%$ (Kuchia x JC-1). Similar results was earlier found by several workers such as Boddepalli et al., (2016), Dubey et al., (2014), Reddy and Patel (2014), Biswas et al., (2013), Makani et al., (2013) and Kumar et al., (2012).

\section{Fruit yield (t/ha)}

In regard to fruit yield, Brinjal-1 x PPL $(173.10 \%)$ showed highest significant positive mid parent heterosis which was followed by JC-1 x Khoruah-1 (113.81\%). The lowest positive heterosis over MP was observed for Kuchia x JC-1 (76.27\%). The maximum and minimum significant positive BP heterosis was observed in the hybrids Brinjal-1 x PPL $(50.19 \%)$ and Brinjal-3 x JC-1 (10.22\%). Kuchia x JC-1 (-0.34\%) showed significant negative BP heterosis. From the present study, it is evident that there was a considerable degree of heterosis for yield and its component characters viz., plant height, days to $50 \%$ flowering, fruit weight and fruits/plant. Timmapur et al., (2008) reported similar results for the yield and its related traits over the commercial check.

\section{Biochemical traits}

\section{Moisture content (\%, FW)}

All the four hybrids showed significant positive heterosis over mid parent presented in Table5. The highest MP heterosis for moisture content was exhibited by JC-1 x
Khoruah-1 (2.10\%) and lowest was recorded by Brinjal-1 x PPL (0.20\%). However, two hybrids showed significant positive heterosis over BP namely, JC-1 x Khoruah-1 (2.07\%) and Brinjal-3 x JC-1 (0.88\%). Brinjal-1 x PPL $(-1.53 \%)$ and Kuchia $\mathrm{x}$ JC-1 $(-0.03 \%)$ recorded significant negative $\mathrm{BP}$ heterosis.

\section{Crude fiber content $(\%, \mathrm{DW})$}

Per cent heterosis over MP and BP for crude fiber content was presented in Table5. The MP heterosis varied from $-24.70 \%$ (Kuchia $\mathrm{x}$ JC-1) to $15.51 \%$ (Brinjal-3 x JC-1). The highest significant positive BP heterosis was observed for the hybrid Brinjal-1 x PPL $(50.00 \%)$ whereas, the lowest positive BP heterosis was recorded for the hybrid JC-1 $\mathrm{x}$ Khoruah-1 (2.04\%) and Kuchia x JC-1 ($15.96 \%)$ recorded highly significant negative $\mathrm{BP}$ heterosis.

\section{Crude protein $(\%, \mathrm{DW})$}

Table5 showed significant positive heterosis over MP for crude protein content and both positive and negative heterosis was observed for BP. Positive heterosis over mid parent ranged from $18.69 \%$ (JC-1 x Khoruah-1) to 9.11\% (Brinjal-3 x JC-1). The hybrid Kuchia x JC-1 (12.72\%), Brinjal-3 x JC-1 (8.14\%) and JC-1 x Khoruah-1 (1.44\%) recorded the highly significant positive BP heterosis. The most significant negative BP heterosis was recorded by the hybrid Brinjal-1 x PPL ($5.13 \%$ ). Only high yielding hybrid never fulfills the consumer and producer requirement. Hence, quality produce is prerequisite for fulfillment of both consumer and producer requirement.

\section{Ascorbic acid (mg/100 g FW)}

The value of per cent heterosis over MP and BP for ascorbic acid content was depicted in Table5. The hybrid Brinjal-3 x JC-1 (5.30\%) 
exhibited the highest significant positive MP heterosis and the lowest positive MP heterosis was recorded by Brinjal-1 x PPL (2.74\%). The hybrid JC-1 x Khoruah-1 (2.33\%) recorded the highest and highly significant positive BP heterosis which was followed by Brinjal-3 x JC-1 (0.93\%) and Kuchia x JC-1 $(0.22 \%)$. The significant negative BP heterosis was recorded for Brinjal-1 x PPL ($1.30 \%)$. This finding were supported by other reports of Kumar et al., (2012) and Pachiyappan et al., (2012)

\section{Solasodine content (mg/100 g DW)}

Two hybrids, JC-1 x Khoruah-1 (-15.52\% and $-9.40 \%)$ and Brinjal-3 x JC-1 (-9.55\% and $8.39 \%$ ) recorded the highly significant negative MP and BP heterosis and Brinjal-1 $\mathrm{x}$ PPL (2.92\% and 11.94\%) and Kuchia X JC-1 $(1.49 \%$ and $26.46 \%)$ showed significant positive MP and BP heterosis.

\section{Total phenol content (mg GAE/g FW)}

Table5 represents per cent $F_{1}$ heterosis over $\mathrm{MP}$ and BP for total phenol content. The high phenols and lower sugars in fruits could help plant to tolerate shoot and fruit borer. In the present investigation, only one hybrid Brinjal1 x PPL (2.26\%) showed highly significant positive mid parent heterosis and other three hybrids namely, Brinjal-3 x JC-1 (-24.57\%), JC-1 x Khoruah1 (-12.74\%) and Kuchia x JC$1(-7.48 \%)$ recorded significant negative MP heterosis. All the four $\mathrm{F}_{1}$ hybrids showed significant positive $\mathrm{BP}$ heterosis.

The highest positive BP heterosis was recorded by the hybrid Brinjal-3 $\mathrm{x}$ JC-1 $(80.41 \%)$ which was followed by Brinjal-1 $\mathrm{x}$ PPL (75.19\%), Kuchia x JC-1 (72.16\%) and JC-1 x Khoruah-1 (65.98\%), respectively. This result is in agreement with the findings of Balwani et al., (2017) found significant positive heterosis over better parent.

\section{Conclusion}

From the present investigation, a wide range of variations in the expression of heterosis for morphological and biochemical traits were observed. These variations are attributed to the potential of parental lines as well as genetic mechanisms.

All the four $\mathrm{F}_{1}$ progeny viz., JC-1 x Khoruah1, Brinjal-3 x JC-1, Brinjal-1 x PPL and Kuchia $\mathrm{x}$ JC-1 were found to be promising for kharif season. Promising $\mathrm{F}_{1}$ hybrids could be utilized as high yielding varieties after systematic multi- location trials in different agro-climatic zones of Assam along with disease- and pest-resistance tests as well as quality tests.

However, attempt to develop superior pure line varieties for kharif season using pedigree breeding method of selection following a superior hybrid may be taken up as a long term goal for the poor and marginal farmers.

\section{References}

Ansari, A.M., Ahmad, E.; Sah, A.; Ali, M.N. and Bhagat, B.K. 2009. Studies of heterosis in brinjal. Green Farming. 2(4): 211-214.

Balwani, A.K.; Patel, J.N.; Acharya, R.R. Gohil, D.P. and Dhruve, J.J. 2017. Heterosis for fruit yield and its component traits in brinjal (Solanum melongena L.). Journal of Pharmacognosy and Phytochemistry. 6(5): 187-190.

Biswas, L.; Mehta, N. and Ansari, S.F. 2013. Hybrid vigour study in brinjal (Solanum melongena L.). Global Journal of Science Frontier Research. 13(9): 7-11.

Boddepalli, V.N.; Dubbey, A.K. and Dabbas, M.R. 2016. Studies of standard heterosis for quantitative traits in eggplant. International Journal of Agricultural Science. 12(1): 38-41. 
Chadha, S.; Singh, B. and Kumar, J. 2001. Heterosis in brinjal. Karnataka Journal of Agricultural Science. 14(4): 1130-1133.

Chowdhury, M.J.; Ahmad, S.; Uddin, M.N.; Quaruzzaman, A.K.M. and Patway, M.M.A. 2010. Expression of heterosis for productive traits in $\mathrm{F}_{1}$ brinjal (Solanum melongena L.) hybrids. Advance in Life Science. 8(2): 8-13.

Desai, K.M.; Saravaiya, S.N.; Patel, A.I.; Tank, R.V. and Patel, D.A. 2016. Heterosis for yield and its relevant characters in brinjal (Solanum melongena L.). Advance in Life Science. 5(13): 5426-5429.

Dubey, R.; Das, A.; Ojha, M.D.; Saha, B.; Ranjan, A. and Singh, P.K. 2014. Heterosis and combining ability studies for yield and yield attributing traits in brinjal (Solanum melongena L.). The Bioscan. 9(2): 889-894.

Dudhat, N.M.; Savaliya, J.J.; Sharma, L.K. and Kelalya, D.S. 2013. Heterosis for earliness and plant stature in brinjal (Solanum melongena L.). Society of Science Division Agricultural Technology Programme Research. 8(4): 555-559.

Joshi, N.; Singh, Y.A. and Bhushan, K.B. 2008. Heterosis for different quantitative traits in brinjal (Solanum melongena L.). Pantnagar Journal of Research. 6(2): 266269.

Kumar, S.R.; Arumugam, T.; Anandakumar, C.R. and Rajavel, D.S. 2012. Estimation of heterosis and specific combining ability for yield, quality, pest and disease incidence in eggplant (Solanum melongena L.). Bulletin of Environment Pharmacy and Life Sciences. 2(1): 03-15.
Makani, A.Y.; Patel, A.L.; Bhatt, M.M. and Patel, P.C. 2013. Heterosis for yield and its contributing attributes in brinjal (Solanum melongena L.). The Bioscan. 8(4): 1369-1371.

N.H.B. 2015. Horticulture Data Base. National Horticulture Board, Ministry of Agriculture, Government of India.

Nalini, A.D.; Patil, S.A. and Salimath, P.M. 2011. Heterosis and combining ability analysis for productivity traits in brinjal (Solanum melongena L.). Karnataka Journal of Agricultural Science. 24(5): 622-625.

Pachiyappan, R.; Saravanan, K. And Kumar, R. 2012. Heterosis in yield and yield components in eggplant (Solanum melongena L.). International Journal of Current Agricultural Science. 2(6): 17-19.

Readdy, E.E.P. and Patel, A.I. 2014. Heterosis studies for yield and yield attributing characters in brinjal (Solanum melongena L.). Trends Bioscience 7(3): 377-380.

Singh, K.; Sidhu, A.S. and Kumar, A. 2012. Heterosis for fruit yield and its components in brinjal (Solanum melongena L.). Journal of Horticultural Science. 7(2): 142-144.

Suneetha, Y.; Kathira, K.B.; Patel, J.S. and Srinivas, T. 2008. Studies on heterosis and combining ability in late summer brinjal (Solanum melongena L.). Indian Journal of Agricultural Research. 42(3):171-176.

Timmapur, P.H.; Dharmatti, P.R.; Patil, R.V.; Kajjidoni, S.T. and Naik, K. 2008. Heterosis for yield in brinjal (Solanum melongena L.). Karnataka Journal of Agricultural Science. 21(3): 476-478.

\section{How to cite this article:}

Jamini Saikia, N. S. Barua, D. B. Phookan and Das P. 2019. Heterosis for Morpho-Biochemical Traits in Brinjal (Solanum melongena L.) During Kharif Season. Int.J.Curr.Microbiol.App.Sci. 8(09): 2808-2818. doi: https://doi.org/10.20546/ijcmas.2019.809.324 